\title{
НОВОСТИ ПСИХИАТРИИ
}

\author{
УДК 616.89:159.922.4:316.6(048.82)
}

Для цитирования: Куприянова И.Е., Лебедева В.Ф. Культуральные и социальные аспекты современной психиатрии (по материалам XVII Всемирного конгресса ВПА). Сибирский вестник психиатрии и наркологии. 2018; 1 (98): 116-118. https://doi.org/10.26617/1810-3111-2018-1(98)-116-118

\section{Культуральные и социальные аспекты современной психиатрии (по материалам XVII Всемирного конгресса ВПА)}

\author{
Куприянова И.Е., Лебедева В.Ф.
}

Научно-исследовательский институт психического здоровья, Томский национальный исследовательский медицинский центр Российской академии наук (НИИ психического здоровья Томский НИМЦ)

Россия,634014, Томск, ул. Алеутская, 4

\section{PEЗЮME}

На прошедшем в октябре 2017 г. конгрессе в Берлине большое внимание было уделено вопросам культуральной и социальной психиатрии. Транскультуральные проблемы касались психического здоровья коренного населения, особенностей клинической картины психических расстройств: депрессии, алкоголизма, психосоматических заболеваний. В обсуждении вопросов диагностики и терапии отмечена важность культурально сформулированных интервью в квалификации психического здоровья. Другим важным направлением представленных исследований были данные по психическому здоровью детей, отмечена значимость вовлеченности семей в социальную адаптацию детей с психическими расстройствами. Большое число докладов было посвящено адаптация системы охраны психического здоровья в Европе к нуждам беженцев. Социальные проблемы психиатрии были отражены в докладах, посвященных анализу работы психиатрических служб в Белоруссии, Украине, Азербайджане, Молдавии, Киргизии. Поднимались вопросы коморбидности, превенции, психиатрического образования.

\footnotetext{
Ключевые слова: психическое здоровье, культуральная психиатрия, социальная психиатрия, коморбидность, превенция.
}

8-12 октября 2017 г. в Берлине (Германия) состоялся конгресс Всемирной психиатрической ассоциации. На конгрессе собралось 10000 участников, приглашенных из 130 стран. Основная тема конгресса была определена организаторами как «Психиатрия 21-го века: контекст, противоречия и заинтересованность". В течение этих осенних дней участники имели благоприятную возможность разобраться в текущем состоянии психиатрии, изучить взгляды различных школ и увидеть будущие направления развития в этой области. Информационный фокус конгресса был сосредоточен не только на новых научных открытиях, но и на вопросах превенции, диагностики, лечения и реабилитации больных с психическими расстройствами $[6,8]$. Целью конгресса был не только обмен знаниями между различными специалистами, но и заинтересованный Равноправный диалог психиатров, лиц с психическими расстройствами и их родственниками в Европе и во всем мире.

Открывая конгресс, президент ВПА Dinesh Bugra (Великобритания) отметил, что основная задача Всемирной психиатрической ассоциации - улучшить помощь пациентам с психическими расстройствами через повышение стандартов лечения. Конгресс предоставил уникальную возможность обмениваться академическими, клиническими научными исследованиями для социального взаимодействия, обучения и внедрения новейших наработок в клиническую практику.

Президент конгресса P. Falcai (Германия) поблагодарил всех участников данного форума за активную творческую подготовку к общепсихиатрическому мероприятию.
На пленарном заседании были заслушаны лекции, получившие международные премии. Сэр Simon Wessely (Великобритания) презентовал исследования по синдрому Найджела (люди, которые не имеют психических расстройств, но абсолютно дезадаптированы в современном обществе). J. Angst (Швейцария), лауреат премии Jean Delay, акцентировал внимание собравшихся на проблемах пациентов с психосоматическими расстройствами и на вопросах гипердиагностики депрессии в данной группе больных.

В работе конгресса приняли участие сотрудники НИИ психического здоровья Томского НИМЦ. Начиная с 1996 г. сотрудники института регулярно участвуют в работе форумов Всемирной психиатрической ассоциации. Стало традицией, когда ученые представляют свои данные в коллаборации с исследователями различных стран в форме симпозиума [1, 2, 3, 4]. В этом году был организован симпозиум «Транскультуральные проблемы психического здоровья коренного населения Сибири и Дальнего Востока: клиническая, биологическая гетерогенность и коморбидность» (председатели: Н.А. Бохан и И.Е. Куприянова, Россия). На симпозиуме были обсуждены вопросы психического здоровья и коморбидность аддиктивных состояний среди коренного населения Сибири и Дальнего Востока (Н.А. Бохан, Д.И. Кургак, А.К. Костин - Россия), психическое здоровье подростков в Китае и Сибири (Hu Jian, Na Zhao - КНР, И.Е. Куприянова, Б.А. Дашиева, И.С. Карауш, Т.И. Иванова - Россия), вклад личностного фактора в формирование психических иФ соматических взаимодействий (С.А. Алтынбеков Казахстан, В.Ф. Лебедева, Н.А. Бохан, Т.Г. Бохан - 
Россия), психические расстройства и возможности этнокультурально обусловленной реабилитации детейинвалидов (И.Е. Куприянова, Б.А. Дашиева - Россия).

Представленные доклады были встречены аудиторией с большим интересом. Плодотворная дискуссия оставила благоприятное впечатление у слушателей, и симпозиум отметили как один из интересных организаторы конгресса. В обсуждении новых перспектив развития культуральной психиатрии выступили професcop T. Heise (Германия), профессор J. Weigl (Германия), професcop С. Cianconi (Италия), А. Schaht (Австрия).

Ассоциация культуральной психиатрии, в состав которой входит НИИ психического здоровья, представила несколько симпозиумов, где вектор внимания акцентировался на психическом здоровье иммигрантов $[5,7]$. В частности на симпозиуме «Общество и социальная психиатрия. Интеркультуральное открытие в лечении иммигрантов и этнических меньшинств», организованном под председательством М. SchoulerOsak (Германия) и M. Kastrup (Дания), обсуждалась роль Европейской психиатрической ассоциации в управлении психическим здоровьем иммигрантов (I.T. Graef-Callies, Германия), рассматривалась культуральная компетенция в организации служб психического здоровья иммигрантов (A. Qureshi, Испания), были представлены культурально сформулированные интервью для квалификации психического здоровья мигрантов (H. Rolof, Нидерланды), намечены пути лечения иммигрантов в системе охраны психического здоровья (S. Baarnhielm, Швеция).

Симпозиум «Общество и социальная психиатрия. Улучшение охраны психического здоровья беженцев и ищущих политического убежища», прошедший под председательством S. Baarnhielm (Швеция) и H. Rolof (Нидерланды) был посвящен клиническим проблемам психических расстройств у иммигрантов, особенностям диагностики и терапии. Изменения в диагностике и лечении беженцев были освещены в докладе H. Rolof (Нидерланды), вопросы эмоционального дистресса у ищущих политического убежища в Израиле были отражены в сообщении R. Youngmann (Израиль). Клиническим и социальным опытом приема в психиатрических службах беженцев, совершивших суицидальную попытку, поделился M. Sundvall (Швеция). Адаптация системы охраны психического здоровья к нуждам беженцев и ищущих политического убежища была представлена в докладе S. Baarnhielm (Швеция).

Культуральные вопросы в сфере современной психиатрии тесным образом связаны с семейным окружением и психическим здоровьем детей [2]. Это направление представлял симпозиум «Семья и транскультуральная психиатрия» (председатели: J. Yang - КНР, R.A. Baldawi - Швеция).

Роль семейного окружения в социальном функционировании детей и подростков в Чили проанализирована в докладе R. Kohn (США). Поддержке интеркультуралных семей в Японии было посвящено сообщение T. Akajama (Япония). Взаимообусловленность психического здоровья и функционирования семьи в Китае отражена в презентации J. Yang (КНР). Клиническое наблюдение за иммигрантами из Ближнего Востока в Швеции позволило проследить R.A. Baldawi (Шве- ция), как влияет изгнание на семейные связи и структуру семьи. На симпозиуме, посвященном факторам риска при суицидальном поведении, был представлен доклад И.С. Карауш, И.Е.Куприяновой «Дети с сенсорными нарушениями: проблемы депрессии и суицидального риска».

Социальные проблемы активно обсуждались на симпозиуме «Современные достижения в российской психиатрии» (председатели: П.В. Морозов, В.Н. Краснов). «О методологических подходах к психиатрии: различные взгляды на современное понимание коморбидноси в психиатрии» доложил В.Н. Краснов. Взаимоотношениям психического здоровья и ревматических заболеваний, внедрению результатов исследований в клиническую практику было посвящено сообщение Д.Ю. Вельтищева. «Комплексное здравоохранение для пациентов с психическими расстройствами: работа по направлению к сервисным разработкам» рассмотрено в презентации Г. Костюка. «Психологическое лечение шизофрении: инсайты от клинической психологии» стало темой сообщения Н. Семеновой, М. Кулыгиной. Вопросы дифференциальной превенции суицидального поведения обсуждались Б.С. Положим на симпозиуме «Суицид и неотложная психиатрия». Профессор кафедры психиатрии СибГМУ Н.А. Корнетов принял участие в президентском симпозиуме с докладом «Коморбидность - интегративный подход психиатрии в клинической медицине».

Симпозиум «Общество и социальная психиатрия (председатели: П.В. Морозов и О.А. Скугаревский) собрал исследователей из стран бывшего СССР. Вполне естественно, что здесь дискутировались вопросы охраны психического здоровья в этих регионах. Динамичным выглядело сообщение «Альянс: психиатрия и общество против отчуждения» (А. Васильева, Н. Незнанов). Охрана и превенция психического здоровья в Азербайджане в течение последних 25 лет была проанализирована Н. Исмаиловым. Современная тенденция перехода от стационарной психиатрии к альтернативным формам психиатрической помощи была представлена в докладе Т. Салако (Киргизстан). Состояние психиатрии в Молдова: 25 лет развития и взгляд в будущее было освещено в презентации Е. Синицы.

П.В. Морозов, Н.А. Марута председательствовали на симпозиуме «Психическое здоровье в Восточной Европе», в ходе его работы обсуждалась каникулярная подготовка психиатров Восточной Европы ВПА зоны (Н. Марута, Украина), обозревались последние 25 лет современной психиатрии (О.А. Скугаревский, Беларусь), ВПА-Сервье Академия как важный источник психиатрических журналов ВПА зоны 10 (П.В. Морозов), развитие скрытого ресурсного потенциала как одна из приоритетных реформ сервиса психического здоровья в Кыргызстане (Т. Салака, Киргизия).

Дружественная атмосфера конгресса, демократизм общения, взаимопонимание, толерантность к иным взглядам - всё это способствовало плодотворному обогащению знаниями ученых разных стран. Было отмечено, что психиатрия является наиболее комплексной, интеллектуально насыщенной медицинской специальностью и находится на стадии все большего понимания об изменениях в мозге и их влиянии на индивидуальное, социальное и культуральное функционирование. 


\section{КОНФЛИКТ ИНТЕРЕСОВ}

Авторы заявляют об отсутствии конфликта интересов в связи с публикацией данной статьи.

\section{ИСТОЧНИК ФИНАНСИРОВАНИЯ}

Авторы заявляют об отсутствии финансирования при проведении исследования.

\section{ЛИТЕРАТУРА}

1. Семке В.Я., Куприянова И.Е., Шушпанова Т.В. Психическое здоровье населения Сибири и Дальнего Востока. Журнал неврологии и психиатрии им. С.С. Корсакова. 2007: 107 (3): 78.

2. Семке В.Я., Куприянова И.Е., Дашиева Б.А. Психическое здоровье школьников: транскультуральный аспект. Томск, 2006: 162.

3. Семке В.Я., Бохан Н.А. Транскультуральная аддиктология. Томск : Изд-во Том. ун-та, 2008: 588.
4. Семке В.Я., Эрдэнэбаяр Л., Бохан Н.А., Семке А.В. Транскультуральная наркология и психотерапия. Томск: Изд-во Том. ун-та, 2001.

5. De Luca V. Cultural psychiatry in a timeline perspective. World Cultural Psychiatry Research Review. 2014; 9 (2): 1-2.

6. Carta M.G., Patten S., Nardi A.E. \& Bhugra D. Mental health and chronic diseases: a challenge to be faced from a new perspective. International Review of Psychiatry. 2017; 29 (5): 373376.

7. Tseng W., Bartocci G., Rovera G., Infante V., De Luca V. The future of cultural psychiatry. World Cultural Psychiatry Research Review. 2014; 9 (2): 27-39.

8. Miresco M.J., Kirmayer L.J. The persistence of mind-brain dualism in psychiatric reasoning about clinical scenarios. American Journal of Psychiatry. 2006; 163 (5): 913-918.

Поступила в редакцию 2.11.2017 Утверждена к печати 5.02.2018

Куприянова Ирина Евгеньевна, д.м.н., профессор, ведущий научный сотрудник отделения пограничных состояний.

Лебедева Валентина Федоровна, л.м.н., главный врач клиники.

Куприянова Ирина Евгеньевна, irinakupr@rambler.ru

УДК 616.89:159.922.4:316.6(048.82)

УДК 616.89:159.922.4:316.6(048.82)

For citation: Kupriyanova I.E., Lebedeva V.F. Cultural and social aspects of modern psychiatry (materials of XVII World Congress of the WPA). Siberian Herald of Psychiatry and Addiction Psychiatry. 2018; 1 (98): 116-118. https://doi.org/10.26617/1810-31112018-1(98)-116-118

\section{Cultural and social aspects of modern psychiatry (materials of the XVII World Congress of the WPA)}

\section{Kupriyanova I.E., Lebedeva V.F.}

Mental Health Research Institute, Tomsk National Research Medical Center, Russian Academy of Sciences Aleutskaya Street 4, 634014, Tomsk, Russian Federation

\section{ABSTRACT}

During the held in October 2017 Congress of Berlin, much attention was paid to issues of cultural and social psychiatry. Transcultural problems rocked mental health of the indigenous population, clinical features of mental disorders: depression, alcoholism, psychosomatic disorders. In the discussion of issues of diagnosis and therapy the importance of culturally formulated interview in the qualifications of mental health was noted. Another important aspect of the research was data on mental health of children, the importance of large families in the social adaptation of children with mental disorders was noted. A large number of reports was devoted to the adaptation of the system of mental health in Europe to the needs of refugees. Social problems of psychiatry were reflected in the reports on the analysis of the work of mental health services in Belarus, Ukraine, Azerbaijan, Moldova, and Kyrgyzstan. The issues of comorbidity, prevention, mental health education were raised.

Keywords: mental health, cultural psychiatry, social psychiatry, comorbidity, prevention.

\section{REFERENCES}

1. Semke V.Ya., Kupriyanova I.E., Shushpanova T.V. Psikhicheskoe zdorov'e naseleniya Sibiri i Dal'nego Vostoka [Mental health of the population of Siberia and the Far East]. Zhurnal nevrologii i psikhiatrii im. C.C. Korsakova - S.S. Korsakov Journal of Neurology and Psychiatry. 2007: 107 (3): 78 (in Russian).

2. Semke V.Ya. Kupriyanova I.E., Dashiyeva B.A. Mental health of schoolchildren: transcultural aspect. - Tomsk: 2006: 162 (in Russian).

3. Semke V.Ya., Bokhan N.A. Transcultural addictology. Tomsk: Publishing House of Tomsk University, 2008: 588 (in Russian)

4. Semke V.Ya., Erdenebayar L., Bokhan N.A., Semke A.V. Transcultural Addictology and Psychotherapy. Tomsk: Publishing House of Tomsk University, 2001 (in Russian).
5. De Luca V. Cultural psychiatry in a timeline perspective. World Cultural Psychiatry Research Review. 2014; 9 (2): 1-2.

6. Carta M.G., Patten S., Nardi A.E. \& Bhugra D. Mental health and chronic diseases: a challenge to be faced from a new perspective. International Review of Psychiatry. 2017; 29 (5): 373376.

7. Tseng W., Bartocci G., Rovera G., Infante V., De Luca V. The future of cultural psychiatry. World Cultural Psychiatry Research Review. 2014; 9 (2): 27-39.

8. Miresco M.J., Kirmayer L.J. The persistence of mind-brain dualism in psychiatric reasoning about clinical scenarios. American Journal of Psychiatry. 2006; 163 (5): 913-918.

Received November 2.2017 Accepted February 5.2017

Kupriyanova Irina E., MD, Professor, leading researcher of Borderline States Department, Mental Health Research Institute, Tomsk National Research Medical Center, Russian Academy of Sciences, Tomsk, Russian Federation.

Lebedeva Valentina F., MD, chief physician of clinic, , Mental Health Research Institute, Tomsk National Research Medical Center, Russian Academy of Sciences, Tomsk, Russian Federation.

Kupriyanova Irina E., irinakupr@rambler.ru 